\title{
REALISTIC MATHEMATICS EDUCATION (RME) SEBAGAI SEBUAH PENDEKATAN PADA PENGEMBANGAN MODUL MATEMATIKA BERBASIS TEORI MULTIPLE INTELLIGENCES HOWARD GARDNER
}

\author{
REALISTIC MATHEMATICS EDUCATION (RME) AS AN \\ APPROACH TO DEVELOPMENT OF MATHEMATICAL MODULE \\ BASED ON MULTIPLE INTELLIGENCES HOWARD GARDNER \\ THEORY \\ Nuzulul Faidah ${ }^{1}$, Ruhban Masykur ${ }^{2}$, Siska Andriani ${ }^{3}$, Lina Herlina ${ }^{4}$ \\ ${ }^{1,2,3}$ Prodi Pendidikan Matematika Fakultas Tarbiyah dan Keguruan Universitas Islam Negeri Raden Intan \\ Lampung \\ ${ }^{4}$ SMP N 2 Jatinangor Sumedang Jawa Barat \\ E-mail: faidahnuzulul@gmail.com
}

\begin{abstract}
This study aims to develop modules based on the Multiple Intelligences Theory of Howard Gardner using the Realistic Mathematics Education (RME) approach in class VIII Middle School. This research is an $R \& D$ research which stages using the development of Borg and Gall. The instrument used in this study uses a questionnaire given to material experts and media experts to test the feasibility of this module. The research results that have been developed are feasible to be used in proper learning are used seen from the results of the validation of material experts and media experts. On the results of the media expert test obtained an average of $80 \%$ with the Criteria "Good" while the results of the material expert test obtained an average value of $84 \%$ with the criteria "Very Good". Student responses to the small group test obtained an average value of $79 \%$ with the criteria "Good", while the response of students in the field test obtained an average value of $88 \%$ with the criteria "Very Good".
\end{abstract}

Keywords: mathematics module, multiple intelligences theory, realistic mathematics education (RME) approach

\begin{abstract}
Abstrak: Penelitian ini bertujuan untuk mengembangkan modul berbasis Teori Multiple Intelligences Howard Gardner menggunakan pendekatan Realistic Mathematics Education (RME) di kelas VIII SMP. Penelitian ini merupakan penelitian R\&D yang tahapannya menggunakan pengembangan Borg and Gall. Instrumen yang digunakan dalam penelitian ini menggunakan angket yang diberikan kepada ahli materi dan ahli media untuk menguji kelayakan modul ini.Hasil penelitian yang telah dikembangkan layak digunakan dalam pembelajaran layakdigunakandilihat dari hasil validasi ahli materi dan ahli media. Pada hasil uji ahli media diperoleh rata-rata sebesar $80 \%$ denganKriteria "Baik" sedangkan pada hasil uji ahli materi diperoleh nilai rata-rata sebesar $84 \%$ dengankriteria "BaikSekali". Adapun respon siswa pada uji kelompok kecil diperoleh nilai rata-rata sebesar 79\% dengan kriteria "Baik", sedangkan respon siswa pada uji lapangan diperoleh nilai rata-rata sebesar $88 \%$ dengan kriteria "Baik Sekali".
\end{abstract}

(C) 2019 Unit Riset dan Publikasi Ilmiah FTK UIN Raden Intan Lampung

Kata Kunci: modul matematika, teori multiple intelligences, pendekatan realistic mathematics education (RME) 


\section{PENDAHULUAN}

Pendidikan merupakan usaha sadar untuk mewujudkan suasana belajar dan proses pembelajaran agar siswa secara aktif mengembangkan potensi dirinya untuk memiliki kepribadian, kecerdasan, serta keterampilan yang diperlukan dirinya dan masyarakat (Yusnita, Irda, R.Masykur 2016). Pendidikan merupakan serangkaian kegiatan yang berdimensi luas, kompleks dan dipengaruhi oleh banyak variable (Masykur, Nofrizal, and Syazali 2017).

Matematika merupakan ilmu yang diajarkan pada setiap jenjang pendidikan (Masykur, Nofrizal, and Syazali 2017). Matematika penting untuk dipelajari dan diterapkan dalam proses pembelajaran. Namun, jika dilihat dilapangan menunjukkan bahwa hasil belajar matematika masih rendah. Rendahnya minat belajar matematika, disebabkan asumsi anak terhadap pelajaran matematika terasa sulit, apalagi dengan metode pengajaran guru yang kurang menarik, yaitu guru menerangkan sementara siswa mencatat (Putra and Sibarani 2015).

Melihat kenyataan di atas maka guru diharuskan memberikan inovasi-inovasi dengan cara memberikan bahan ajar yang untuk menunjang keberhasilan dalam proses belajar mengajar salah satunya yaitu modul. Modul menjadi solusi terbaik sebagai acuan selain buku yang ada sehingga siswa dapat belajar dengan sistematis.

Padahal ini modul dapat membantu siswa dalam menemukan konsep-konsep dalam aktivitas sendiri atau belajar secara berkelompok yang akan menyebabkan pembelajaran lebih bermakna. Pemecahan konsep-konsep diperlukan pemikiran dan gagasan yang kreatif untuk meyelesaikan model matematika jika dalam proses pembelajaran menggunakan suatu pendekatan yang tepat. Salah satu pendekatan yang dapat mengembangkan kemampuan siswa adalah Pendekatan Realistic Mathematics Education (RME).

RME menggabungkan apa itu matematika, bagaimana siswa belajar matematika dan bagaimana matematika harus diajarkan.(Hadi 2017) Pendekatan Realistic Mathematics Education menekankan bagaimana siswa menemukan kembali konsep-konsep dalam matematika melalui masalah yang realistik bagi siswa.(Ja'far, Sunardi, and K 2014)

Selain menggunakan pendekatan Realistic Mathematics Education untuk meningkatkan siswa lebih aktif dalam belajar, terdapat salah satu solusi yaitu dengan membuat modul berbasis Teori Multiple Intelligences. Pembelajaran berbasis Teori Multiple Intelligences ini menuntut siswa mengembangkan kecerdasan yang dimiliki oleh masingmasing siswa dan memiliki tanggungjawab masing-masing, dimana siswa diharuskan mengembangkan berbagai macam kecerdasan yang dimilikinya.

Berdasarkan data yang diperoleh di SMP N 1 kalianda menunjukkan bahwa hasil belajar siswa sebagian besar belum memenuhi Kriteria Ketuntasan Minimal (KKM) atau dapat dikatakan masih rendah. Oleh karena itu diperlukan adanya bahan ajar yang mampumendukung proses belajar agar lebih efektif. Hal tersebut membuat peneliti menganggap perlu adanya penelitian dan pengembangan ini untuk dilakukan dengan tujuanya itu mengembangkan modul matematika berbasis Teori Multiple Intelligences Howard Gardner menggunakan Pendekatan Realistic Mathematics Education (RME) dan mengetahui criteria kelayakan serta respon siswa terhadap produk yang dikembangkan tersebut.

\section{METODE PENELITIAN}


Penelitian ini menggunakan metode penelitian dan pengembangan (Research and Development). Adapun prosedur penelitian yang digunakan yaitu mengacu pada desain pengembangan Borg and Gall yang meliputi :potensidanmasalah, pengumpulan data, desain produk, validasi desain, revisi desain, uji coba produk, revisi produk, uji coba pemakaian, revisi produk dan produk massal. Namun langkah yang digunakan dalam pengembangan modul ini peneliti hanya membatasi 7 langkah sajadari 10 langkah tersebut karena keterbasan waktu dan biaya (Sugiyono 2013; Ghaliyah, Bakri, and Siswoyo 2015; Irwandani et al. 2017; Nurussaniah and Nurhayati 2016).

Produk yang dihasilkan berupa modul matematika berbasis Teori Multiple Intelligences Howard Gardner menggunakan pendekatan Realistic Mathematics Education (RME). Data yang telah di dapat dari hasil validasi, respon guru, serta respon siswa dianalisa menggunakan Skala Likert. Adapun rumus untuk menghitung presentase kelayakan adalah sebagai berikut :

$$
\mathrm{P}=\frac{\mathrm{S}}{N} \times 100 \%
$$

$\mathrm{P}=$ Presentase kelayakan

$\mathrm{S}=$ Jumlah Skor yang diperoleh

$\mathrm{N}=$ Jumlah Skor maksimum

(Arikunto 2010)

Adapun angket respon terhadap produk yang dikembangkan terdapat 5 pilihan jawaban yang diberikan kepada validator ahli materi dan ahli media dengan ketentuan sebagai berikut :

Tabel 1. Pedoman Skor Penilaian Ahli

\begin{tabular}{lc}
\hline \multicolumn{1}{c}{ Kriteria } & Skor \\
\hline Sangat Baik (SB) & 5 \\
Baik (B) & 4 \\
Cukup Baik (CB) & 3 \\
Kurang Baik (KB) & 2 \\
Tidak Baik (TB) & 1 \\
\hline
\end{tabular}

(Sugiyono 2013)

Sedangkan Angket respon siswa terhadap produk juga terdapat 5 pilihan jawaban dengan ketentuan sebagai berikut :
Tabel 2. Pedoman Penskoran Angket Respon Siswa

\begin{tabular}{lc}
\hline \multicolumn{1}{c}{ Kriteria } & Skor \\
\hline Sangat Setuju(SS) & 5 \\
Setuju (S) & 4 \\
Cukup (C) & 3 \\
Tidak Setuju (TS) & 2 \\
Sangat Tidak Setuju (STS) & 1 \\
\hline
\end{tabular}

Hasil persentase angket yang didapat baik dari angket validasi maupun angket respon siswa dikategorikan sesuai dengan interpretasi pada tabel berikut ini :

Tabel 3. Range Presentase dan Kriteria Kualitatif Program

\begin{tabular}{cc}
\hline Presentase (P) & Kriteria \\
\hline $\mathrm{P}>80 \%$ & Baik Sekali \\
$60 \%<\mathrm{P} \leq 80 \%$ & Baik \\
$40 \%<\mathrm{P} \leq 60 \%$ & Cukup \\
$20 \%<\mathrm{P} \leq 40 \%$ & Kurang \\
$\mathrm{P} \leq 20 \%$ & Sangat Kurang \\
\hline (Arikunto 2010)
\end{tabular}

\section{HASIL DAN PEMBAHASAN}

Hasil utama dari penelitian dan pengembangan ini adalah modul berbasis Teori Multiple Intelligences Howard Gardner menggunakan Pendekatan Realistic Mathematics Education (RME) pada materi kubus dan balok. Penelitian ini mengacu pada desain pengembangan Borg and Gall yang terdiri 7 langkah penelitian yang meliputi potensi dan masalah. Pengumpulan data, desain produk, validasi desain, revisi desain, uji coba produk, dan revisi produk.

\section{a. Potensi dan masalah}

Pada tahap ini dilakukan analisis kebutuhan terhadap produk yang akan dikembangkan melalui wawancara tidak terstruktur terhadap guru SMP N 1 Kalianda Ibu Siti Mutmainah,S.Si bahwa di kelas VIII guru hanya menggunakan buku sebagai bahan ajar, sehingga siswa kurang bersemangat dalam proses pembelajaran.

\section{b. pengumpulan data}


Setelah melihat potensi dan masalah yang ada di lapangan, Selanjutnya dilakukan pengumpulan dan pengolahan data dari bebearpa literatur buku dan beberapa jurnal yang mendukung untuk digunakan sebagai bahan perencanaan produk yang akan dikembangkan.

\section{c. Desain produk}

Setelah semua data yang dibutuhkan telah terkumpul baik itu dari literatur buku ataupun jurnal maka dapat digunakan sebagai bahan pertimbangan untuk analisis kebutuhan sumber belajar baru berupa modul yang akan dikembangkan.

\section{d. ValidasiDesain}

Validasi desain merupakan kegiatan untuk menilaiapakah rancangan produk akan efektif atau tidak. Setelah produk desain produk selesai, maka dilakukan validasi produk dengan cara menghadirkan beberapa pakar atau tenaga ahli yang sudah berpengalaman untuk menilai produk yang baru dirancang tersebut. Validasi desain diuji oleh ahli materi dan ahli media. Adapunhasilpenilaianvalidator dapat dilihat pada tabel di bawah ini :

Tabel 4. Hasil Validasi oleh Ahli Materi

\begin{tabular}{|c|c|}
\hline Rata-rata Skor & kriteria \\
\hline $84 \%$ & Baik Sekali \\
\hline \multicolumn{2}{|c|}{ Tabel 5. Hasil Validasi oleh Ahli Media } \\
\hline Rata-rata Skor & kriteria \\
\hline $80 \%$ & Baik \\
\hline
\end{tabular}

Berdasarkan pada tabel di atas, diperoleh skor rata-rata hasil validasi ahli materi dan ahli media. Adapun rata-rata skor oleh ahli materi diperoleh sebesar 84 $\%$ dengan criteria Baik Sekali. Sedangkan rata-rata skor oleh ahli media diperoleh sebesar $80 \%$ dengan criteria Baik, hal ini menunjukkan bahwa produk pengembangan yang dihasilkan layak digunakan dan dapat dilanjutkan ketahap selanjutnya.

\section{e. Revisi Desain}

Kelayakan produk tidak terlepas dari masukan dan saran oleh para ahli. Perbaikan-perbaikan yang dilakukan terhadap produk yang dikembangkan berpedoman dari masukan-masukan dan saran yang diperoleh dari para ahli validasi, namun produk yang dihasilkan sudah layak dan dapat dilanjutkan ketahap berikutnya.

\section{f. Uji coba produk}

Setelah produk melalui tahap validasi oleh ahli materi dan ahli media serta telah selesai diperbaiki, selanjutnya produk di uji cobakan dengan uji coba kelompok kecil dan uji coba lapangan. Uji coba kelompok kecil terdiri dari 10 orang siswa dan pada ujicoba lapangan terdiri dari 30 siswa. Adapun Hasil uji coba produk dapat dilihat pada tabel di bawah ini:

Tabel 6. Hasil Rata-rata Respon siswa

\begin{tabular}{ccc}
\hline $\begin{array}{c}\text { Nama } \\
\text { Sekolah }\end{array}$ & $\begin{array}{c}\text { Uji skala } \\
\text { Kecil }\end{array}$ & $\begin{array}{c}\text { Uji Coba } \\
\text { lapangan }\end{array}$ \\
\hline $\begin{array}{c}\text { SMP N 1 } \\
\text { kalianda }\end{array}$ & $79 \%$ & $88 \%$ \\
\hline
\end{tabular}

\section{g. Revisi produk}

Berdasarkan hasil uji coba produk, apabila respon siswa mengatakan bahwa produk ini menarik, maka dapat dikatakan bahwa produk modul telah selesai dikembangkan sehingga menghasilkan produk akhir. Jika produk belum sempurna maka hasil dari uji coba ini dijadikan bahan perbaikan dan penyempurnaan produk yang dibuat, sehingga dapat menghasilkan produk akhir berupa pembelajaran matematika yang layak dan sangat menarik.

\section{KESIMPULAN}

Modul matematika berbasis Teori Multiple Intelligences Howard Gardner Menggunakan Pendekatan Realistic Mathematics Education (RME) pada materi kubus dan balok yang telah dikembangkan layak digunakan dilihat 
dari hasil validasi ahli materi dan ahli media. Pada hasil uji ahli media diperoleh rata-rata sebesar $80 \%$ dengan Kriteria "Baik" sedangkan pada hasil uji ahli materi diperoleh nilai rata-rata sebesar $84 \%$ dengankriteria "Baik Sekali". Respon siswa pada modul ini dalam uji coba kelompok kecil diperoleh nilai ratarata sebesar 79\% dengan kriteria "Baik", sedangkan respon siswa pada uji coba lapangan diperoleh nilai rata-rata sebesar 88\% dengan kriteria "BaikSekali".

\section{DAFTAR PUSTAKA}

Arikunto, Suharsimi. 2010. Evaluasi Program Pendidikan. Jakarta: PT Bumi Aksara.

Ghaliyah, Sitti, Fauzi Bakri, and Siswoyo. 2015. "Pengembangan Modul Elektronik Berbasis Model Laerning Cycle 7E Pada Pokok Bahasan Fluida Dinamik Untuk Siswa SMA Kelas XI." Prosiding Seminar Nasional Fisika (E-Journal) SNF2015 IV: 149-54.

Hadi, Sutarto. 2017. Pendidikan Matematika Realistik.

Irwandani, Irwandani, Sri Latifah, Ardian Asyhari, Muzannur Muzannur, and Widayanti Widayanti. 2017. "Modul Digital Interaktif Berbasis Articulate Studio'13: Pengembangan Pada Materi Gerak Melingkar Kelas X." Jurnal Ilmiah Pendidikan Fisika AlBiruni 06 (2): 221-31.

Ja'far, Muhammad, Sunardi Sunardi, and Arika Indah K. 2014. "Pengembangan Perangkat Pembelajaran Berbasis Karakter Konsisten Dan Teliti Menggunakan Pendekatan Realistic Mathematics Education ( RME ) Pada Bab Kesebangunan Dan Kekongruenan Bangun Datar Kelas IX SMP ( The Development of Mathematics Learning Aids Based." Jurnal Edukasi UNEJ 1 (2): 29-35.

Masykur, Rubhan, Nofrizal, and Muhammad Syazali. 2017.
"Pengembangan Media Pembelajaran Matematika Dengan Macromedia Flash." Al-Jabar: Jurnal Pendidikan Matematika 8 (2). Nurussaniah, and Nurhayati. 2016. "Pengembangan Penuntun Praktikum Fisika Dasar 1 Berbasis Guided Inquiry Untuk Meningkatkan Kemampuan Berpikir Kritis Mahasiswa." Priosiding Seminar Nasional Fisika (E-Journal) V: 6368.

Putra, jaya Dwi, and Pitta Armita Sibarani. 2015. "Penerapan Pendidikan Realistic Mathematics Education(RME) Berbasisi LKS Dalam Meningkatkan Kemampuan Komunikasi Matematis Siswa VIII SMP Baptis Batam Tahun Pelajaran 2013/2014." Jurnal Program Studi Pendidikan Matematika 4 (1): 29 38.

Sugiyono. 2013. "Metode Penelitian Pendidikan Pendekatan Kuantitaif, Kualitatif, Dan R\&D." Metode Penelitian Pendidikan Pendekatan Kuantitaif, Kualitatif, Dan R\&D. https://doi.org/10.1007/s13398-0140173-7.2.

Yusnita, Irda, R.Masykur, Suherman. 2016. "Modifikasi Model Pembelajaran Gerlach Dan Ely Melalui Integrasi Nilai-Nilai Keislaman Sebagai Upaya Meningkatkan Kemampuan Representasi Matematis." Al-Jabar: Jurnal Pendidikan Matematika 7 (1): 29-38. 